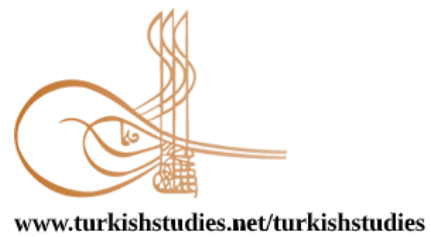

Turkish Studies

\title{
Sınıf Öğretmeni Adaylarının COVID-19 Pandemi Sürecine İlişkin Görüşleri
}

\author{
Pre-Service Classroom Teachers' Opinions Regarding the COVID-19 Pandemic Process
}

\author{
Nil Duban* - Fatma Gül Şen**
}

\begin{abstract}
COVID-19 has been described as an infectious disease caused by the most recently discovered coronavirus. With the closure of schools due to the COVID-19 pandemic in our country, a free distance education system was launched by the Ministry of Education on 23 March 2020 with a national level television and internet-based curriculum. Weekly course programs have been restructured in all schools at primary, secondary and high school level, and the necessary compensatory training support has started to be provided via EBA (Education Information Network) on the internet and television screens. In the field of educational sciences and social sciences related to Covid-19, there are few studies yet. In order to shed light on the researches in the context of educational sciences, it has been considered important to reveal the awareness of teacher candidates regarding the COVID-19 pandemic process. In this context, the aim of this study is to determine the opinions of pre-service teachers regarding the COVID-19 pandemic process. Within the scope of this research, which was approved by the ethics committee, the opinions of 72 pre-service teachers were obtained through an open-ended questionnaire. In the research carried out with the scanning model, the data were analyzed by descriptive analysis technique. It was concluded that the pre-service teachers who participated in the study welcomed the closure of the schools due to the priority of the health of the children and that they were satisfied with the rapid transition to distance education in this process. In the research, elementary teacher candidates are of the opinion that teachers should follow their students and provide the necessary academic and psychological support by conducting live lessons, writing on the phone via SMS or WhatsApp. It is concluded that the elementary teacher candidates think that parents should also help their children.
\end{abstract}

Structured Abstract: COVID-19 has been described as an infectious disease caused by the most recently discovered coronavirus. The World Health Organization (WHO) announced on 11 March 2020 that the new type of corona virus has now reached the level of 'pandemic' by overcoming the epidemic dimension. More than 1.5 billion students and young people worldwide have been affected by school and university closings due to the COVID-19 outbreak. With the closure of schools due to the COVID-19 pandemic in our country, a free distance education system was launched by the Ministry of Education on 23 March 2020 with a national level television and internet-based curriculum. Weekly course programs have been restructured in all schools

\footnotetext{
* Prof. Dr., Afyon Kocatepe Üniversitesi, Eğitim Fakültesi, Temel Eğitim Bölümü

Prof. Dr., Afyon Kocatepe University, Faculty of Education, Primary School Department ORCID 0000-0002-8851-0114

nily@aku.edu.tr

** Yük.Lisans Öğrencisi, Afyon Kocatepe Üniversitesi, Sosyal Bilimler Enstitüsü

Graduate Student, Afyon Kocatepe University, Instute of Social Sciences

ORCID 0000-0002-9144-5069

fatmagulsen.25@hotmail.com

Cite as/ Atıf: Duban, N., Şen, F. G. (2020). Sınıf öğretmeni adaylarının COVID-19 pandemi sürecine ilişkin görüşleri. Turkish Studies, 15(4), 357-376. https://dx.doi.org/10.7827/TurkishStudies.43653

Received/Geliș: 17 May/Mayıs 2020

Accepted/Kabul: 10 August/Ağustos 2020

Copyright (C) MDE, Turkey
} 
at primary, secondary and high school level, and the necessary compensatory training support has started to be provided via EBA (Education Information Network) on the internet and television screens.

The COVID-19 pandemic has shown its effect all over the world and countries are intensively looking for ways to get rid of the negative effects of this process. When the literature is examined, although there are many studies related to corona virus and COVID-19 in the field of medicine due to the nature of the process, there are very few studies in educational sciences and social sciences yet. In order to shed light on the researches in the context of educational sciences, it has been considered important to reveal the awareness of teacher candidates regarding the COVID-19 pandemic process. In this context, the aim of this study is to determine the opinions of pre-service teachers regarding the COVID-19 pandemic process. For this purpose, answers were sought for the following questions:

How do the pre-service teachers evaluate the pandemic process in the context of the century we live in?

How do pre-service teachers evaluate the pandemic process in the context of its effects on primary school students?

What are the opinions of pre-service teachers about the duties of teachers and parents during the pandemic process?

This research includes the quantitative dimension of a mixed method study that has been approved by the ethics committee. In this quantitative research dimension, the opinions of the elementary teacher candidates were taken through an open-ended questionnaire. The participants of this research are 72 preservice teachers who are studying in the 3rd grade in the education faculty where one of the researchers is teaching Science and Technology Teaching-II. The research data were collected from prospective teachers who participated in the research voluntarily in April 2020. A measurement tool consisting of a total of four open-ended questions was prepared by the researchers to determine the opinions of prospective teachers. In the research carried out with the scanning model, the data were analyzed by descriptive analysis technique.

In current research, it is concluded that the candidates of the elementary teachers have been confronted with many epidemic diseases for centuries and believed that the scientific process is the most valuable method to be trusted in diseases. It was concluded that the pre-service teachers who participated in the study welcomed the closure of the schools due to the priority of the health of the children and that they were satisfied with the transition to distance education in this process. At the end of the research, it was revealed that the pre-service teacher candidates worried that the absence of going to school would cause children to suffer socially and psychologically and that they would not be able to acquire some of the values and habits they gained during face-to-face education in the same way as distance education at home.

In current research, elementary teacher candidates are of the opinion that teachers should follow their students and provide the necessary academic and psychological support by conducting live lessons, writing on the phone via SMS or WhatsApp. In the research, it was concluded that the prospective teachers believed that it would be beneficial for parents to keep their family relations warm at home, study together and read books, get new hobbies, cook, and provide free access to many activities online, and guide their family to cultural activities. Another of the results obtained in this research is that the importance of using technology effectively and efficiently, that pre-service teachers will have some awareness at the end of the Covid-19 pandemic process, and that learning will be at the forefront of learning and learning. Their beliefs that they will be understood.

Keywords: Pre-service teachers, Corona virüs, COVID-19, COVID-19 Pandemic, Pandemic.

Öz: COVID-19, en son keşfedilen koronavirüsün neden olduğu bulaşıcı hastalık olarak tanımlanmıştır. Ülkemizde COVID-19 pandemisi dolayısıyla okulların kapanmasıyla birlikte Millî Eğitim Bakanlığı tarından 23 Mart 2020'de ulusal düzeyde televizyon ve internet tabanlı bir müfredatla ücretsiz bir uzaktan eğitim sistemi başlatılmıştır. İlkokul, ortaokul ve lise düzeyinde tüm okullarda haftalık ders programları yeniden yapılandırılmış, EBA (Eğitim Bilişim Ağı) ile internet üzerinden ve televizyon ekranlarından gerekli telafi eğitimi desteği sunulmaya başlanmıştır. Covid-19 ile ilgili eğitim bilimleri ve sosyal bilimler alanında henüz yok denecek kadar az çalışmaya rastlanmaktadır. Eğitim bilimleri bağlamında yapılacak araştırmalara 1şık tutabilmek bağlamında öğretmen adayların COVID-19 pandemi sürecine ilişkin farkındalıklarını ortaya çıkarmak önemli görülmüştür. Bu bağlamda yapılan bu araştırmanın amacı sınıf öğretmeni adaylarının

Turkish Studies, 15(4) 
COVID-19 pandemi sürecine ilişkin görüşlerini belirlemektir. Etik kurul onayı alınan bu araştırma kapsamında, 72 sınıf öğretmeni adayının görüşü açık uçlu anket yoluyla alınmıştır. Tarama modeliyle yürütülen araştırmada veriler betimsel analiz tekniği ile çözümlenmiştir. Araştırmaya katılan öğretmen adaylarının çocukların sağlıklarının öncelikli olması nedeniyle okulların kapatılmasını olumlu karşıladıkları ve bu süreçte hızla uzaktan eğitime geçilmesinden memnun oldukları sonuçlarına ulaşılmıştır. Araştırmada sınıf öğretmeni adayları, öğretmenlerin canlı dersler yaparak, telefonda mesaj ya da WhatsApp aracılı̆̆ıla yazışarak, öğrencilerini takip etmeleri ve gereken akademik ve psikolojik desteği vermeleri gerektiği görüşündedirler. Sınıf öğretmeni adayları, velilerin de çocuklarına yardımcı olması gerektiğini düşündükleri sonucuna ulaşılmıştır.

Anahtar Kelimeler: Sınıf öğretmeni adayları, Corona virüs, COVID-19, COVID-19 Pandemisi, Pandemi.

\section{Giriş}

Korona virüsler, hayvanlarda veya insanlarda hastalığa neden olabilecek büyük bir virüs ailesidir. İnsanlarda, birkaç korona virüsün soğuk algınlığından Orta Doğu Solunum Sendromu (MERS) ve Şiddetli Akut Solunum Sendromu (SARS) gibi daha şiddetli hastalıklara kadar solunum yolu enfeksiyonlarına neden olduğu bilinmektedir (WHO, 2020). Yeni tip korona virüsü de, SARS ve bazı soğuk algınlığı türleriyle aynı virüs ailesine bağlı yeni bir virüstür. Daha önce, bu hastalığa "2019 yeni koronavirüs" veya "2019-nCoV" deniyordu. İlk kez Çin'in Wuhan kentinde tanımlanan yeni koronavirüsün neden olduğu hastalığa "COVID-19" adı verilmiştir. (UNICEF, 2020).

Aralık 2019'da Çin'de viral pnömoni ile hastaneye başvuran hasta sayısı daha sonra yeni koronavirüs hastalığının (COVID-19) neden olduğunu ortaya koymuş ve COVID-19 salgını çok hızlı bir biçimde pandemiye dönüşmüştür (Yıldız ve diğerleri, 2020). 30 Ocak 2020'de Dünya Sağl1k Örgütü, COVID-19'un uluslararası endişe verici bir halk sağlığı acil durumunun patlak vereceğini belirtmiştir (Güner ve diğerleri, 2020). Dünya Sağlık Örgütü, yeni tip korona virüsün artık salgın boyutunu aşarak 'pandemi' seviyesine geldiğini ise 11 Mart 2020'de duyurmuştur.

Dünya genelinde 1,5 milyardan fazla öğrenci ve genç, COVID-19 salgını nedeniyle okul ve üniversite kapanışlarından etkilenmiştir. UNESCO, ülkeleri, özellikle daha savunmasız ve dezavantajlı topluluklar için okul kapanmalarının derhal etkisini azaltma ve uzaktan öğrenme yoluyla herkes için eğitimin sürekliliğini sağlama çabalarında destek vermektedir. Bu bağlamda, UNESCO tarafından başlatılan Küresel Eğitim Koalisyonu, bu ani ve benzeri görülmemiş eğitim kesintisi döneminde çocuklar ve gençler için kapsayıcı öğrenme firsatlarını kolaylaştırmaya çalışmakta, bir takım öneriler sunmaktadır (UNESCO, 2020). 26 Mart 2020'de Facebook'ta UNESCO IITE, (Uluslararası Eğitimde Teknoloji Topluluğu) (ISTE) ve diğer kuruluşlarla ortaklaşa olarak, gençlerin daha güvenli bir şekilde ihtiyaç duydukları yetkinlik ve becerileri geliştirmelerine yardımcı olacak dersler ve kaynaklar sağlamak için dijital okuryazarlık programı olan Get Digital'i başlatmıştır. Buradaki kaynaklar hem sınıfta hem de evde eğitimciler ve aileler tarafından kullanılmak üzere tasarlanmıştır (IITE-UNESCO, 2020). Genel yaşantı bağlamında da pandemi döneminde insanlar kendilerini virüsten korumak istedikleri için evde kalmaya başlamışlar böylece iletişim teknolojileri ve dijitalleşme evde kalan kişilerin dünyayla bağlantı kurmasını sağlayan araçlar olmuştur (Aldemir \& Avşar, 2020).

Ülkemizde pandemi dolayısıyla okulların kapanmasıyla birlikte Milli Eğitim Bakanlığı tarından 23 Mart 2020'de ulusal düzeyde televizyon ve internet tabanlı bir müfredatla ücretsiz bir uzaktan eğitim sistemi başlatılmıştır. İlkokul, ortaokul ve lise düzeyinde tüm okullarda haftalık ders programları yeniden yapılandırılmış, EBA (Eğitim Bilişim Ağı) ile internet üzerinden ve televizyon ekranlarından gerekli telafi eğitimi desteği sunulmaya başlanmıştır. EBA, öğretmenler ile öğrenciler arasında iletişim kurmak, eğitim hayatları boyunca kullanabilecekleri materyalleri sağlamak üzere kurulan bir portaldır. COVID-19 pandemisi sürecinde TV için uyarlanmış EBA programları 18 farklı kanalda yayınlanmakta, her eğitim seviyesine altı farklı kanal tahsis 
edilmektedir. EBA TV Programları, her sınıf düzeyinde derslerin öğretim programlarının kazanımları çerçevesinde 20 şer dakikalık dersler olarak düzenlenmiştir. Binlerce video ve animasyon hazırlanmıştır. 100'den fazla öğretmen derslerini gönüllü olarak TV için hazırlayıp ve sunmaktadır. Bununla birlikte gerek TVden gerekse internetten takip edilebilen EBA programında akı1lı telefonlardan erişilebilen uygulamalar da yer almaktadır.

COVID-19 pandemisi tüm dünyada etkisini göstermiş ve ülkeler yoğun bir biçimde bu sürecin olumsuz etkilerinden kurtulmanın yollarını aramaya başlamıştır. Alan yazın incelendiğinde yaşanan sürecin doğası gereği tıp alanında corona virüs ve COVID-19 ile ilgili çok fazla çalışmaya rastlanmasına karşın, eğitim bilimleri ve sosyal bilimler alanında henüz yok denecek kadar az çalışmaya rastlanmaktadır. Alan yazındaki bu boşluğun doldurulması ve yaşanan sürecin etkilerinin ortaya konup çözüm arayışlarının başlayabilmesi için tüm bilim dallarında araştırmaların yapılması gerekmektedir. Belki birkaç yıl etkisi sürecek olan pandeminin eğitime yansımalarının da çok farklı boyutlarda (psikolojik, sosyolojik, teknolojik, metodolojik vb.) olacağ 1 kaçınılmaz bir gerçektir. Bu gerçekten yola çıkarak, pandeminin etkileri halâ çok sıcak bir biçimde kendini göstermeye devam ederken öğretmenliğe adım atması beklenen adayların COVID-19 pandemi sürecine ilişkin farkındalıklarını ortaya çıkarmak önemli görülmüştür. Bu bağlamda yapılan bu araştırmanın amacı sınıf öğretmeni adaylarının COVID-19 pandemi sürecine ilişkin görüşlerini belirlemektir. Bu amaç çerçevesinde şu sorulara yanıt aranmıştır:

1. Sınıf öğretmeni adayları yaşanan pandemi sürecini içinde bulunduğumuz yüzyıl bağlamında nasıl değerlendirmektedir?

2. S Sınıf öğretmeni adayları pandemi sürecini ilkokul öğrencilerine etkileri bağlamında nasıl değerlendirmektedir?

3. Sınıf öğretmeni adayları pandemi sürecinde öğretmenlere ve velilere düssen görevler hakkındaki görüşleri nelerdir?

\section{Yöntem}

\section{Araştırmanın modeli}

$\mathrm{Bu}$ araştırma 27.07.2020 tarih, 5 Nolu toplantı ve 2020/117 numaralı karar ile etik kurul onayı alınmış bir karma yöntem çalışmasının nicel boyutunu içermektedir. Bu nicel boyutta tarama modeline göre desenlenen araştırma kapsamında sınıf öğretmeni adaylarının COVID-19 Pandemi sürecine ilişkin görüşleri betimlenmiştir. Anketler, ucu açık ve kapalı olmak üzere detaylı bir şekilde ayrılabilen formatlar şeklinde yapılır. Açık uçlu sorular bir araştırmacının insanların ne düşündüğünü bilmek istediğinde kullanılır ve yanıtlanması istenen anketlerin e-posta yoluyla kat1lımc1lara yollanmas1 günümüzde popülaritesi giderek artan durumlardan biridir (Christensen, Johnson ve Turner, 2015; Arthur, Waring, Coe ve Hedges, 2017). Bu araştırma kapsamında sınıf ögretmeni adaylarına e-posta ile gönderilen ucu açık soru formatında anket kullanılmıştır.

\section{Katılımcilar}

$\mathrm{Bu}$ araştırmada, seçkisiz olmayan örnekleme türlerinden uygun örnekleme kullanılmıştır. $\mathrm{Bu}$ örnekleme kullanılırken, muhtemel katılımcılara çalışmaya katılmak için uygun olup olmadıkları sorulur ya da çalışmaya katılması kolay bir katılımeı grubu oluşturulur (Christensen, Johnson ve Turner, 2015). Bu araştırmanın katılımcıları, araştırmacılardan birinin Fen ve Teknoloji Öğretimi-II dersini yürüttüğü eğitim fakültesinde 3. sinıfta öğrenim görmekte olan 72 sinıf

öğretmeni adayıdır. COVID-19 pandemisi nedeniyle uzaktan eğitimle yürütülen dersler esnasında yaşanan pandemiye, bilim ve teknolojiye ilişkin tartışmalarda olgunlaşan süreç, katılımcıların eposta yoluyla hazırlanan açık uçlu sorulara verdikleri yanıtlarla şekillenmiştir. 


\section{Veri Toplama Aracı}

Araştırma verileri, Nisan 2020 tarihinde araştırmaya gönüllü olarak katılan öğretmen adaylarından toplanmıştır. Araştırmacılar tarafından öğretmen adaylarının görüşlerini belirlemek üzere, toplam dört adet açık-uçlu sorudan oluşan bir ölçme aracı hazırlanmıştır. İç geçerliği sağlamak için açık uçlu sorulardan oluşan anket iki alan uzmanına verilmiş ve uzmanların incelemeleri sonucu sorulara son şekli verilmiştir. Daha sonra, bu soruların işlerliğini ölçebilmek için beş öğretmen adayı üzerinde pilot çalışma yapılmıştır. Soruların açık ve anlaşılır olup olmadığını, verilen yanıtların sorulan soruların yanıtlarını yansıtıp yansıtmadığını belirlemek amacıyla araştırmacılarla birlikte bir alan uzmanı da, pilot uygulama sonuçlarını incelemiştir. Bu çalışmanın sonunda, soru maddelerinin iç geçerliği saptanmıştır. Böylece son şekli verilen açık uçlu sorular şunlardır:

1. Bir sınıf öğretmeni adayı olarak yaşanan pandemi sürecini genel olarak nasıl değerlendiriyorsunuz? (içinde bulunduğumuz yüzyıl çerçevesinde yanıtlayınız)

2. Okulların pandemi dolayısıyla kapanmış olmasının ilkokula devam eden çocuklar açısından olumlu ve olumsuz yanları nelerdir?

3. COVID-19 pandemisi sürecinde öğretmenlere düşen görevler nelerdir?

4. COVID-19 pandemisi sürecinde velilere düşen görevler nelerdir?

\section{Verilerin analizi}

$\mathrm{Bu}$ araştırmada, toplanan veriler, betimsel analiz tekniğine göre çözümlenmiştir. Betimsel analizin amac1, ham verilerin okuyucunun anlayabileceği ve isterlerse kullanabileceği bir biçime sokulmasıdır. Betimsel çözümlemede elde edilen veriler daha önceden belirlenen temalara göre özetlenip yorumlanır ve bulguların sunumunda doğrudan alıntılara sık sık yer verilir (Altunışık ve diğerleri, 2001; Yıldırım ve Şimşek, 2013). Uygulanan form önce birden yetmiş ikiye kadar numaralandırılmış, daha sonra verilen yanıtlar araştırmacılar tarafindan tek tek okunarak soruların altında oluşturulan yeni kodlarla özetlenip yorumlanmıştır. Oluşan kodlar ana tema altında alt tema ve kategoriler olarak sunulmuştur. Katılımcıların yanıtlarından yapılan doğrudan alıntılar yoluyla bu kategoriler desteklenmiştir.

\section{Bulgular}

Sınıf Öğretmeni adaylarının COVID-19 Pandemi sürecine ilişkin görüşlerini almak amaciyla yapılan bu araştırmada, analizler sonucunda ortaya çıkan tema, alt tema ve kategoriler Tablo 1'de sunulmuştur.

Sınıf Öğretmeni adaylarının COVID-19 Pandemi sürecine ilişkin görüşlerini almak amacıyla yapılan bu araştırmada, analizler sonucunda ortaya çıkan tema, alt tema ve kategoriler Tablo 1'de sunulmuştur. 


\begin{tabular}{|c|c|c|c|}
\hline Tema & & Alt temalar & Kategoriler \\
\hline \multirow{6}{*}{$\begin{array}{l}\text { COVID-19 } \\
\text { Süreci }\end{array}$} & \multirow{6}{*}{ Pandemi } & 21. yy. ve COVID-19 Pandemisi & $\begin{array}{l}\text { Bilim Tarihi Açısından } \\
\text { Dijitalleşen dünya ile çelişki açısından } \\
\text { Yaşanan sıkıntılar }\end{array}$ \\
\hline & & $\begin{array}{l}\text { COVID-19 Pandemisi ve eğitim } \\
\text { Süreci }\end{array}$ & $\begin{array}{l}\text { Alınan Önlemler } \\
\text { Beklentiler/Avantaja dönen durumlar }\end{array}$ \\
\hline & & $\begin{array}{l}\text { COVID-19 Pandemisinde Görev ve } \\
\text { Sorumluluklar }\end{array}$ & Öğretmenlere Yönelik \\
\hline & & & Velilere Yönelik \\
\hline & & $\begin{array}{l}\text { COVID-19 Pandemisi Sonrasında } \\
\text { Yaşam }\end{array}$ & Eğitsel Değişiklikler \\
\hline & & & Toplumsal Değişiklikler \\
\hline
\end{tabular}

\section{Yy. ve COVID-19 Pandemisi Alt Temasına İlişkin Bulgular}

COVID-19 Pandemi Süreci teması altında 21. yy. ve COVID-19 Pandemisi alt temas1 yer almaktadır. Bu alt temanın altında iki kategori ortaya çıkmıştır. Bu alt tema ve kategorileri Tablo 2 'de gösterilmiştir.

Tablo 2: Sınıf Öğretmeni adaylarının 21. yy. ve COVID-19 Pandemisi alt teması ve kategorileri

\begin{tabular}{ll}
\hline Alt tema & Kategoriler \\
\hline 21. yy. ve COVID-19 Pandemisi & Bilim Tarihi Açısından \\
& Dijitalleşen dünya ile çelişki açısından \\
\hline
\end{tabular}
sunulmuştur.

"Bilim tarihi” ve "Dijitalleşen dünya ile çelişkisi” kategorilerine ilişkin görüşler Tablo 3’te

Tablo 3: Sınıf Öğretmeni Adaylarının Kategorilere İlişkin Görüşleri

\section{Kategori}

Bilim Tarihi Açısından

\section{Görüşler}

"Geçmişte insanlar belki de veba salgınından haberi olmadan yaşamını yitiriyorlardı."

"MS 980-1037 yılları arasında yaşamış olan tıp insanı İbn-i Sina'yı anlatan 1957 yılı Özbekistan yapımı filmde, İbn-i Sina'nın "veba" ile ilgili verdiği tavsiyelere baktığımızda günümüz pandemisi için verilen güncel tavsiyeler olduklarını görmekteyiz. 1900'lü yılların başında "İspanyol gribi" diye adlandırılan salgınla beraber 50 milyon insan kaybedildiğini görüyoruz."

“11. yüzyılda görülen cüzzam, 14. yüzyılda veba, 1. Dünya savaş1 sırasındaki tifüs salgını büyük kayıplara sebep olmuş bazı salgın hastalıklardandır. Tarihte böyle dönemlerden güçlenerek çıkmış birçok devlet bulunuyor. Şu an ki dünya düzenini, gelişen teknoloji 
ve bilimi göz önüne aldığımızda daha önceki salgınlara göre daha avantajlı haldeyiz. $\mathrm{Bu}$ avantajı kullanarak Covid-19 virüsünü en kısa sürede atlatacağımıza inanıyorum."

“Geçmişten günümüze bakıldığında Veba, Sars, Ebola gibi ölümcül virüsler vardı. Ancak geçmiş yıllarda olmuş salgınlar gibi bu süreçte de aşı bulunamamış olması halen bazı şeylerin dünyada eksik olduğunu gösterir."

“Tarihe bakıldığı zaman büyüklerimizin de yine birçok salgın hastalıklarla mücadele ettiği ve bu sürecin sonunda büyük kayıplar verdikleri görülmektedir. Bunlardan bir tanesi de Veba hastalığıdır. $\mathrm{Bu}$ hastalıkta yine kitlesel ölümlere sebep olmuş, sosyal, ekonomik, psikolojik olarak büyük yıkımlar gerçekleştirmiştir. Aslında geçmişe baktığımız zaman bu hastalıkların bu kadar önünün alınamamasının bir sebebi ise bilime bu kadar önem verilmemesi ve teknolojinin bu kadar gelişmiş olmamasıydı."

“ Öncelerde vebanın tedavisi olmadığından dolayı yakalananların sonu ölümle sonuçlanıyordu fakat günümüzde tedavi edilebiliyor. ", "Dünya bu tür salgınlarla ilk kez karşılaşmadı. Sadece İspanyol gribinde(1918-1919) 40-50 milyon arasında insan hayatını kaybetti."

"Dünya tarihinde daha önce de Covid-19 gibi bulaşıcılığı yükssek olan hastalıklar ortaya çıkmıştır ve oldukça fazla can kaybı yaşanmıştır."

“Tarih boyunca Veba, Kolera, Ebola, Kuş gribi, Domuz gribi, Çiçek hastalığı vb. birçok salgın hastalık Dünya'da milyonlarca insanın ölümüne sebep oldu. Hatta insanlar savaşlardan çok salgın hastalıklardan öldü."

"Tarihte korona salgınıyla benzetebileceğimiz veba salgını olmuştur. Bu salgın 1347- 1351 yıllarında yaşanmış ve yine Çin merkezli dünyaya yayılmıştır. Bu salgınının etkisi o kadar büyük yaşanmıştır ki 100 milyona yakın insan hayatını yitirmiştir."

"Yaşadığımız yüzyılı düşünürsek daha düne kadar Marsa insanların koloniler halinde ziyaretini konuşuyorduk. Bugün ise görünmeyen bir virüs tüm dünyaya el yıkama dersi veriyor."

Dijitalleşen dünya ile çelişki açısından
“Teknolojinin çok ilerlediğini sandığımız bir çağda uzaya araç gönderme, robotlar üretme gibi pek çok alanda gelişen teknoloji malesef bir pandemi olayında sağlık sektörünün aslında geri olduğunu göstermiştir. Kimse böyle bir durumu düşünemezdi lakin geçmişten ders çıkarmamız gerekirdi. İspanyol salgını, Mers, Sars gibi, Kolera salgını gibi birçok pandemi olayda gerçekleşmiştir geçmişte. Geçmişe göre yaşama alanlarındaki kalitemizi yükseltmek için yapılan teknolojik gelişmeler sağlık alanında yeterli olmadığ gözler önüne serilmektedir.”

"Günümüzde teknolojinin bu kadar gelişmesine rağmen insanlık olarak bu virüs karşısında çaresiz kaldık. Virüs kısa sürede küresel bir tehdit haline geldi. İnsanlık olarak başka gezegenlerde hayat ararken bu virüs hayatımızı tam manasıyla durdurdu."

"Teknolojik alet olarak kolay pazarlanabilen aletleri seçmek yerine 
sağlık için olan teknolojik aletlere de önem vermeleri gerekirdi belki o zaman bu kadar sorunla karşılaşmazlardı. Bilim doğru sorulan her soruya bir şekilde cevap veriyor. Bilimin verdiği doğru cevapları teknolojide kullanamazsak sonunda büyük kayıplar yaşarız."

"Sosyalleşmenin, teknolojinin, bilimin, ulaşımın ve daha birçok alanın fazlasıyla gelişme gösterdiği bu çağda, ne yazık ki bir virüs için hızlı bir çözüm yok, evde kalıp bu süreci atlatmayı bekliyoruz."

"Kanserin tedavisi bulundu" haberlerini okuduğumuz çağda hala nasıl bu virüsün aşısının veya çaresinin bulunamadığına hala şaşıyorum. Tıp çok ilerlemiş, yapay zekalar yapılıyor ama bir virüsün aşısı bulunamıyor gerçekten bana çok ilginç geliyor."

"Yı1lar önce aya çıkabilen insanoğlu 21.yüzyılda bir virüse karşı neredeyse çaresiz kaldı.",

“21. Yüzyılda yaşamamıza rağmen hala bir aşısının bulunamıyor olması beni çok şaşırtıyor."

“Bu dönemde yaşanan kötü olaylar yaşadığımız yüzyılı göz ününe alırsak Tıpta ne kadar ileri gidersek gidelim bazen aşılamayacak kadar büyük problemler olduğunu gösteriyor.',

"Covid-19un virüs kaynaklı olduğunu biliyoruz ama kesin bir tedavi yöntemimiz yok. Ve tek yapmamı gereken sokağa çıkmamak. Bir de kolonya var... Belki de bundan yüzyıllar sonra Türkiye tarihinde korona salgınını araştıran bir bilim insanı çözüm yolu olarak kolonya kullandığımızı yazacak ve onu okuyan küçük bir kız da bunu çok ilkel bulacak... ,

Katılımcı öğretmen adayları, pandemi ya da epidemi şeklinde ifade edilmese bile yüzyıllar boyunca insanoğlunun birç̧ok salgın hastalıkla yüzleşmek zorunda kaldığını ifade etmiştir. Özellikle kısıtlı olanaklar çerçevesinde salgın hastalıklarla mücadele etmenin zor olduğunu ancak günümüzde gelişen tıp bilimleri ve teknoloji sayesinde sürecin daha kolay olacağını umut etmişlerdir. Geçmiște yaşanan salgın hastalıklardan ders çıkarılması gerektiğini ve 21. Yüzyılın olanakları ile pandemiye daha kolay çözüm bulunacağını temenni ettiklerini belirtmişlerdir. Bununla birlikte 21. Yüzyılın hızla ilerleyen bilim ve teknolojisine rağmen halâ bir salgın hastalığa kısa sürede çözüm bulunamamasını yadırgadıklarını ifade etmişlerdir. Sınıf öğretmeni adaylarının bilim tarihinden yola çıkarak yanıtlar vermeleri ve bilimsel sürecin hastalıklarda güvenilecek en kıymetli yöntem olduğunu düşünmeleri Fen ve Teknoloji Öğretimi dersi kapsamında ele alınan konulardan (Bilim tarihi, Bilimin doğası, Bilim felsefesi ve paradigmalar) ve diğer bilimsel yöntem derslerinden esinlendiklerini düşündürmektedir.

\section{COVID-19 Pandemisi ve Eğitim Süreci Alt Temasına İlişsin Bulgular}

COVID-19 Pandemisi ve Eğitim Sürecine alt teması altında üç kategori ortaya çıkmıştır. $\mathrm{Bu}$ alt tema ve kategorileri Tablo 4'te gösterilmiştir. 
Tablo 4: Sınıf Öğretmeni adaylarının COVID-19 Pandemisi ve Eğitim Süreci alt teması ve kategorileri

\begin{tabular}{ll}
\hline Alt tema & Kategoriler \\
\hline & Yaşanan skkıtılar \\
COVID-19 Pandemisi ve Eğitim Süreci & Alınan Önlemler \\
& Beklentiler/Avantaja dönen durumlar
\end{tabular}

"Yaşanan sıkıntılar" ve "Alınan Önlemler" ve "Beklentiler/Avantaja dönen durumlar" kategorilerine ilişkin görüşler Tablo 5 'te sunulmuştur.

Tablo 5: Sınıf Öğretmeni Adaylarının Kategorilere İlişkin Görüşleri

Kategoriler

Yaşanan sıkıntılar

Görüşler

"Çocuklar okulda yüz yüze öğretmenin gözetiminde ve dönütleriyle daha iyi öğreniyorlardı. Ama uzaktan eğitimde yüz yüze eğitimdeki gibi daha iyi, daha etkileşimli öğrenemiyorlar."

"Öncelikle öğrenciler sınıf ortamında alacakları saygı, sosyallik gibi özellikleri online eğitimle alamıyorlar."

"Her sınıf seviyesindeki öğrenciler öğretmenin eksikliğini hissetti. Özellikle 1.sınıfların fazlasıyla olumsuz etkilendiğini düşünüyorum. Bence bizim için en doğru eğitim örgün, yüz yüze sınıf ortamında yapılmış eğitim. Çünkü hiçbir aile öğretmen kadar çocuğuyla ilgilenemiyor."

"Öğrenciler evlerinde eğitim gördükleri için belli bir uyku düzenleri, çalışma düzenleri kalmıyor. Öğrencinin okuldaki gibi bir disiplin alanı ve zorunluluğu olmadığı için bazı günler çalışma yapmıyorlar diye görüyorum çevremden.”

"Herkes aynı şartlara sahip değil ve bu evde verilen eğitimleri alamayan öğrenciler de var. Hadi diyelim ki her öğrencinin alması sağlandı, kimin katılıp katılmayacağı veya ne kadar katılacağı gibi durumlar da var.'

"Sürekli ev içerisinde olmak insanlara halsizlik ve beraberinde tembellik getiriyor. İnsanların bu duruma alışması ileride büyük bir soruna işe eğitime $\mathrm{vb}$. odaklanamamaya sebep açacak diye düşünüyorum."

"Salgın hastalık sebebiyle okulların eğitime uzun süreli ara vermesi sonucunda tüm çocuklar evlere kapandı ve günlük rutinleri altüst oldu. İlk defa böyle bir olayla karşılaşan çocuklar bunu anlamlandırmakta güçlü çektiler. Özellikle ilkokul çağındaki çocuklar virüs kavramını kafalarında somutlaştıramadılar. Anne babası veya medya tarafından virüs kavramına sürekli maruz bırakılan bazı çocuklar ise virüsün canavar ve hayalet gibi kötü bir şey olabileceğini düşündüler. Ayrıca bu canavarın kendi anne, baba ve yakınlarına zarar vereceğini düşünerek kaygılandılar. Bu kaygı bozukluğu davranış bozukluklarını da beraberinde getirdi." 
"Sosyal ortamın olmadığı, çocukların arkadaşlarıyla teneffüslere doyamadığı, iyi ya da kötü her durum ve koşulda öğretmenlerine koştuğu, doğru ya da yanlış soru ve cevaplarla eğlenceli derslerin olduğu günlerden uzak kalmak çocuklarımızı psikolojik olarak etkileyebilir ve fazlasıyla öfkeli ve hırçın yapabilir."

"Çocuklar için oyun oynamak, sınıftaki arkadaşlarıyla diyalog kurmak hem fiziki hem de sosyal yönlerinin gelişimine katk1 sağlamaktadır. Velilerin bu dönemde çocukların evde sürekli ders çalışmaları üzerine çocuklarına baskı kurmaları, çocuklar üzerinde olumsuz etkiler yaratır ."

\section{Alınan Önlemler} Beklentiler/Avantaja dönen
durumlar
"Okulların tatil edilmesi ile virüsün yayılmasına büyük bir önlem alınmıştır."

"Eğitimin aksamaması için yapılan uzaktan eğitimin sadece internet ortamına bağlı kalmayıp televizyon üzerinden de verilmesinin eğitimde firsat eşitliğini sağladığını düşünüyorum. Milli eğitim bakanlığının hazırladığı programların içeriğine eleştirel baksam da kısa sürede iyi iş çıkardıklarını düşünüyorum.."

"Okulların uzun süreli tatil olmasını sağlık açısından doğru buluyorum. İlkokul çağındaki çocuklar çok fazla hareketli oldukları için hijyen konusunu pek düşünmüyorlar."

"Okulda sürekli temas halinde olan çocukların sağlığının korunması ve izole edilmesi anlamında kendi evlerinde olması eminim ki onlar için çok daha etkili ve faydalı bir yöntem."

"EBA 'dan dersler uzaktan eğitim şeklinde devam etmektedir. Uzaktan eğitim öğrencilerin eğitim açısından eksik kalmamaları için çok büyük bir artı durumundadır."

"Vaka sayılarının artmaya başlaması ile Sağlık Bakanlığından; okullara ara verilip uzaktan eğitime geçilmesi, belirli yaş aralıklarının sokağa çıkmaması, şehirlerarası ulaşımın durdurulması, maskesiz dışarı çıkmamak gibi birçok önlem alındı ve alınmaya devam etmekte. "

"Televizyonlardan rahatllkla yapmamız gereken şeyleri sosyal mesafe, temizlik, hijyen, maske, sokağa çıkmama gibi durumları görerek tedbir almamız sağlanıyor.",

"Sağlık, eğitim, sosyal hayat, ekonomi, sanayi, tarım, turizm, ulaşım gibi birçok alanda sınırlamalar konulmuştur.',

"İlkokul, ortaokul, lise ve üniversitelerde uzaktan eğitime geçildi. 65 yaş üstü ve kronik hastalığı olanların sokağa çıkması sınırlandırıldı bu yasakların dışında sürekli yapılan evde kalın sokağa çıkmayın uyarıları ve son olarak bazı illere giriş-çıkışların yasaklanması ve 20 yaş ve altının sokağa çıkma yasağı getirildi.",

"Okullara ara verilip uzaktan eğitimle devam ettirilmesi, belli yaş aralıklarının sokağa çıkma yasağı, şehirlerarası giriş çıkışların bir süreliğine durdurulması, sokağa maskesiz çıkmama gibi bir sürü önlemler alındı ve alınmaya da devam ediyor. ",

"Boş vakit çok olduğu için çocuklar yeni hobiler edinebilirler. El becerilerini geliştirecek resim, oyuncaklarına kıyafet tasarlama, annesine yemek yaparken yardım etme gibi etkinliklerde bulunabilirler."

"Çocuklar ailesi ile kaliteli zaman geçirebilir. Yeni bilgiler öğrenebilir. Öz bakım becerilerini geliștirebilir.”

"Evde bulunmalarının olumlu yanı aileleriyle daha fazla vakit geçirmeleri, etkileşimde bulunmaları sayesinde aile bağlarının da 
güçlenmiş olmasıdır."

"Yararlı tarafları olarak çocukların dinlenme firsatı bulduklarını, değişik aktiviteler için bolca zamanlarının olması, aileleri ile daha çok zaman geçirmesi, okula başladıkları zaman daha dinç bir şekilde derslere konsantre olmaları olduğu düşüncesindeyim."

"Sonraki yıllar için bu gibi durumlarla karşılaşıldığında başa çıkabilecek donanımlı bilim insanları, doktorlar, öğretmenler yetiştirebiliriz.',

" $\mathrm{Bu}$ süreçte hem öğrenciler hem de veliler teknolojiyle daha çok iç içe aslında hep iç içeydi ama bu sefer gerçekten teknolojiyi faydalı bir şekilde kullanmaya başladılar. Birçok sistem kuruldu ve öğrenciler, veliler bu sistemi çözüp eğitimi bir şekilde devam ettirmeye çalışıyorlar bence bu durum 21.yy becerilerinden bilgi, medya ve teknoloji becerisi açısından güzel bir adım. ",

" Öğrencilerimiz için ücretsiz bilgi erişimine açılmış birçok program yer almaktadır. Her türden kitap, tiyatro, sinema, konser, spor, eğitici belgeseller, online kurslar, vb. daha birçok sosyal aktiviteler internette erişime açıktır. Süreç boyunca her öğrencinin sadece derslerle yetinmeyip bütün bu sosyal aktivitelere ilgisi ve katılımının olacağını düşünüyorum.',

" Sürecin olumlu tarafı diyebileceğim galiba aile iletişimidir. Anne ve babası işe gitmeyen çocuklar mutlu olabilirler. Bundan önce anne babaları işe gittikleri için çocuklar aileleriyle vakit geçiremiyorlardı ama şimdi tüm gün aileleriyle birlikteler.",

"'Okullar uzun süre tatil olunca aslında öğretmenlerin ve okulun önemi daha çok anlaşılmış oldu. Öğrencilerin sınıf ortamında olmasının önemi de daha iyi anlaşılmış oldu. ",

Kat1lımcılar pandemi sürecinin tüm insanlık adına çok üzücü ve zorlu bir süreç olduğunu özellikle çocukların sağlıklarının öncelik olması dolayısıyla okulların kapanmasını olumlu bir yaklaşım olarak değerlendirdiklerini belirtmişlerdir. Bununla birlikte evde devam eden yaşamlarında olumsuz tarafin özellikle sosyal anlamda çocukları sıkıntıya sokacağını yüz yüze eğitim sırasında kazanacakları bazı değer ve alışkanlıkları evde benzer bir performansla sergileyemeyeceklerinden endişe ettiklerini ifade etmişlerdir. Öğretmen adayları bu sürecin olumluya dönen (avantaja dönüştürülebilecek) tarafının ise gerek internet gerekse TV erişimli uzaktan eğitimin devreye sokulması olarak görmekte, ayrıca bu dönemin ev içinde aile ilişkilerini sıcak kılmak, yeni hobiler edinmek, yemek yapmak, online birçok etkinliğe ücretsiz erişim sağlayarak kültürlenmek gibi avantajları da beraberinde getireceğini ummaktadırlar. Öğretmen adaylarının çocukların gerek bilişsel gerek duyuşsal gerekse sosyal gelişimlerine yönelik yaptıkları açıklamalar öğretmenlik mesleğine yönelik algılarının gelişmekte olduğunu ve pedagojik anlamda ilerleme kaydettikleri algısını oluşturmaktadır.

\section{COVID-19 Pandemisinde Görev ve Sorumluluklar Alt Temasına İlişskin Bulgular}

COVID-19 Pandemisinde Görev ve Sorumluluklar alt teması altında ortaya çıkan kategoriler "Öğretmenlere Yönelik" ve "Velilere Yönelik”tir. Bu kategorilere ilişkin görüşler Tablo 6'da sunulmuştur.

Tablo 6: Sınıf Öğretmeni adaylarının COVID-19 Pandemisinde Görev ve Sorumluluklar alt temas1 ve kategorileri

\begin{tabular}{l|l}
\hline Alt tema & Kategoriler \\
\hline \multirow{2}{*}{ COVID-19 Pandemisinde Görev ve Sorumluluklar } & Öğretmenlere Yönelik \\
& Velilere Yönelik \\
\hline
\end{tabular}


sunulmuştur.

“Öğretmenlere Yönelik" ve "Velilere Yönelik" kategorilerine ilişkin görüşler Tablo 7'de

Tablo 7: Sınıf Öğretmeni Adaylarının Kategorilere İlişkin Görüşleri

Kategoriler Görüsşler

Öğretmenlere Yönelik

"Öğretmenler bu süreçte öğrencileri ile çeşitli uygulamalar sayesinde iletişime geçebilirler. Online ders (Zoom, teamlink vb uygulamalar ile) yapıp öğrencileri takip edebilirler. Öğretmenler aileler ile iletişime geçerek çocukları ile evde oynayabilecekleri oyunları tavsiye edebilirler."

"Öğretmenler bu uzaktan eğitim sürecinde öğrencilerine gereken ilgiyi göstermeliler. Öğrencilerin bu süreçten olabildiğince en az hasarla atlatmalarına yardımcı olmalılar. Bence öğretmenlerin öğrencileriyle telefonla konuşmaları iyi olabilir."

“EBA'yı izledikten sonra öğrencilerini tanıyan onların nasıl hangi konuyu hangi yöntem ve teknikle anlatıldığ zaman verimli olacağını bilen bir öğretmen EBA'da eksik gördüğü yer hakkında öğrencilerine daha iyi öğrenebilmeleri için videolar çekebilir, alıştırmalar hazırlayabilir."

"Uzaktan eğitim bize çocuğun psikolojisini yansitmaz bu yüzden öğretmen öğrencilerle ve velilerle iletişim halinde olmalı ve öğrencilerin sıkıntılarından haberdar olmalıdır örneğin bir WhatsApp grubu kurarak vb. Öğrencilerin velileriyle iletişime geçebilir ve öğrencilerin psikolojilerinden ve içinde bulunduğu ruh halini anlayabilir bu şekilde velilere tavsiyede bulunabilirler."

“Öğretmen Eba'dan anlatılan konuları, niteliklerini takip edip ona göre ailelere ulaşıp o konuları elinden geldiğince pekiştirmeleri için etkinlikler, ödevler vermeli eğer değinilmesi gereken Eba'da yetersiz gördüğü yerler varsa bunları anlatmalı, canlı video, video, ses kaydı şeklinde iletmeli."

“Öğretmenler öğrencilerini motive etmek için ögrencilerine hepimiz aynı saatte şu şarkıyı dinleyeceğiz gibi duyuşsal anlamda öğrencilerini mutlu edecek şeyler yapabilirler."

“Öğretmenler, öğrencilerin öğrenme heveslerini arttırmak için evlerinde oynayabileceği eğlenceli eğitici oyunlar tasarlaması büyük fayda sağlar. "

"CÇocuklara bu sürecin geçici olduğunu iletişime geçerek konuşması gerekir. Görüntülü konferans araması yapılarak öğrencilere moral verilebilir. "

“Öğretmen verdiği araştırmaları gerek ödevleri gerekse çalışma kâğıtlarını arkadaşlarıyla yüz yüze görüşemeseler bile sosyal medya hesaplarından veya telefon ile birbirleri 
ile ortak çalımalar yapmalarını isteyerek öğrenciler arasındaki bağın kopmamasını sağlayabilir. ",

\section{Velilere Yönelik}

"Hijyen konusunda çocukları gerekirse etkinliklerle eğitmeliler. Yedikleri yemeğe dikkat ederek çocukların ve kendilerinin bağışıklıklarına dikkat etmelidirler. Velilerin evde çocuklarıyla beraber etkinlik yapmalılar. Kitapların öneminin bilinciyle çocuklara kitap okuma sevgisini kazandırmalılar."

"Velilere de en az öğretmenler kadar görev düşüyor. Öğretmenin dediklerini yapmalı verdiği ödevleri öğrencilerin yaptığından emin olmalıdır. Öğrencilerin yanlışlarını, eksiklerini ve anlamadığı yerleri takip edip öğretmene bilgi vermelidir. Öğrencilerin bu dönemini en az hasarla atlatmalarını sağlamalıdır. Öğretmene yardımcı olmalıdır."

"Çocuklarının eğitiminin aksamaması için günü iyi planlamalı, EBA TV'yi izletmeli, öğretmeninin verdiği etkinlik ve görevleri yerine getirtmeli ve geri dönüt vererek öğretmenlerle olan iletişimi koparmamalıdırlar."

"Velilerin görevi öncelikle çocukların tatilde olmadıklarını, eğitimlerine devam etmeleri gerektiğini çocuklara hissettirmektir. Derslerini, gününde ve zamanında uygulamalarına dikkat etmeliler."

"Ailelerin çocuklarıyla verimli zaman geçirmesi, birbirlerine destekte bulunması önemli. Çocuklarla birlikte bilim ve sanat üzerine uygulamalar yaparak hem çocukların eğlenmesini, hem de bu alanlarda kendilerini geliştirmelerinin sağlanması bu dönemin verimli geçmesine olanak tanıyacaktır."

"Veliler öncelikle çocuğuna virüsün nasıl bir şey olduğunu açıklamalı ve alınması gereken önlemler anlatıldıktan sonra virüsün alacağımız önlemlerden daha güçlü olmadığını belirterek öğrenciye psikolojik olarak rahatlatıcı şeyler söylenmeli ve öğrencinin bu süreçte stres yapmamasını ve rahat olmasını sağlamalı."

'Veliler çocuklarına; empati kurma, sorumluluk alma, yardımsever olma gibi değerler ile kitap okuma ve kişisel bakım ve temizliğine önem gösterme gibi birçok eylemi alışkanlık haline getirebilmeleri için çalışmalar yapabilir, örnek olabilirler."

"'Burada velilere önemli bir görev düşüyor; çocuğa uygun ders ortamı yaratıp diğer saatlerde de çocuğun sosyal gelişimine katkıda bulunacak etkinlikler yapmak, ögretmenle iletişim halinde olmak velilerin şu dönemde görevi."

“'Bu süreçte pek çok kişi şu anda evde, çocukları ilgisiz bırakmayıp bu zamanı değerlendirmeliler. Gerek 
eğitimleriyle, gerek sağlıklarıyla ilgilenmeli; aile bağlarını güçlendirecek, öğrenciyi genel kültür ve milli değerler açısından da geliştirecek etkinlikler yapmalılar."

“'Ev ortamında erteleme davranışları ve dikkat dağınıklığı olacağından ve bunun da en büyük nedeninin kontrolsüz teknolojik alet ve sosyal medya kullanımı, uyku ve beslenme düzensizliği olduğunu söyleyebiliriz. Dersler dışında kalan boş vakitlerini iyi bir şekilde değerlendirebilmesi için beraber plan yapabilirler."

Öğretmen adayları pandemi sürecinde hem öğretmenlere hem de velilere bir takım görev ve sorumluluklar düştüğünü ifade etmişlerdir. Öğretmenlerin bu süreçte öğrencilerinin bilişsel ve duygusal anlamada yaşadıkları sıkıntıları anlamak ve onlara çözümler üretebilmek için, canlı dersler yapmaları, telefonla kimi zaman görüntülü konuşmalar gerçekleştirmeleri ve çocukların durumunu ailelerden aldıkları dönütlerle takip edip eksiklerini kapamak için önlemler almaları gerektiğini ifade etmişlerdir. Sınıf öğretmeni adaylarının öğretmenlerin bu zorlu süreçte göstermeleri gereken sorumluluk dolu tavırlara yönelik açılamaları adayların mesleki gelişimlerinin olumlu yönde olduğu izlenimini oluşturmaktadır.

Benzer biçimde öğretmen adayları, velilerin çocuklarının sağlıklarına dikkat etmeleri gerektiğini, hijyen konusunda ve diğer öz-bakım becerilerinde çocuklarına yardım etmelerinin yararlı olacağını, uzaktan eğitimi en iyi biçimde takip etmeleri konusunda çocukları izlemelerinin önemli olduğunu, öğrencilerin akademik sorunlarını fark edip öğretmene ileterek öğrenci-öğretmen arasında köprü görevi kurmalarını önermişlerdir. Ayrıca velilerin evde çocuklarıyla birlikte kaldıkları bu süreçte kitap okuma ile sanatsal, sportif ve kültürel aktiviteler yapmaları gerektiğini belirtmişlerdir. Öğretmen adaylarının yaptıkları açıklamalar bir öğretmenin öğrenci-veli-öğretmen sacayağında sahip olması gereken rehberlik, iletişim gibi mesleki bilgi ve becerilerin farkındalığına işaret etmektedir.

\section{COVID-19 Pandemisi Sonrasında Yaşam Alt Temasına İlişkin Bulgular}

COVID-19 Pandemisi sonrasında yaşam alt teması altında ortaya çıkan kategoriler "Eğitsel Değişiklikler" ve "Toplumsal Değişiklikler"dir. Bu kategorilere ilişkin görüşler Tablo 8'de sunulmuştur.

Tablo 8: Sınıf Öğretmeni adaylarının COVID-19 Pandemisi sonrasında yaşam alt teması ve kategorileri

\begin{tabular}{l|l}
\hline Alt tema & Kategoriler \\
\hline \multirow{2}{*}{ COVID-19 Pandemisi Sonrasında Yaşam } & Eğitsel Değişiklikler \\
& Toplumsal Değişiklikler \\
\hline
\end{tabular}

“Eğitsel Değişiklikler” ve "Toplumsal Değişiklikler” kategorilerine ilişkin görüşler Tablo 9'da sunulmuştur.

Tablo 9: Sınıf Öğretmeni Adaylarının Kategorilere İlişkin Görüşleri

\begin{tabular}{ll}
\hline Kategoriler & Görüşler \\
\hline & "Bu süreçte 21. Yüzyıl becerilerimizin birçoğunu etkili bir \\
Ĕgitsel Değişiklikler & şekilde kullanmayı öğreneceğiz. Örneğin bilgi okuryazarlığını \\
& ve medya okuryazarlığın doğru bir şekilde kullanmalıyı ki \\
& gündemdeki haberleri iyice inceleyip nası bilgiler
\end{tabular}


edineceğimize bilebilmeliyiz.”

"Elbette bu yıllardan sonra daha ileri seviye gelişmeler gerçekleşecektir ancak ileride gelişmelerin olması için şimdiden yatırım amaçlı bilgi birikimi ve çalışmalar olmalıdır, çünkü ilerde çıkacak sorunların çözümü geçmişte yaşanmış olaylar ve bulunan bilgilerle aydınlatılarak bulunabilir."

"Sınıf öğretmenleri uzaktan eğitim için kullanabileceği, canlı ders verebileceği programları iyi kullanabiliyor olmalıdır. Artık eğitimler bu yönde olabilir."

"Bu süreçte öğrencilerin eğitimleri için gerek televizyondan gerek internetten ders ve konu anlatımları sayesinde öğrencilerin eğitimine de ülkemizce önem verildi. Bundan sonra ekstra durumlara daha hazırlıklı oluruz."

“Öğrencilerde eğitimin sadece okulda, dört tarafı duvarlarla çevrili bir alanda yapılmadı̆̆ı algısı oluştu."

“'Öğretmenlerimiz de yeni bir eğitim anlayışına geçtiği için farklı bir deneyim ve tecrübe kazanmış olacaklardır. Birçok öğretmenimiz bu sürece geçişte eğitimler aldı. Uzaktan eğitim hepimiz için eğitime karşı farklı bir bakış acısı yaratmış oldu."

"İlkokul, ortaokul, lise ve üniversiteler edildi. Tabi bu bildiğimiz tatiller gibi değildi. Günümüz teknolojisini göz önüne aldığımızda ülkede uzaktan eğitim verilmesine karar verildi. 21.yy'da bir süre de olsa okulların yerini tabletler, televizyonlar ve bilgisayarlar aldı."

“Eğitim açısından okulda kültür derslerinin yanında arkadaşlık, paylaşma gibi pek çok değer de kazandırılıyordu. Değerler eğitimi bakımından da kültür dersleri bakımından da uzaktan eğitimin her çocuk için aynı olmayacağı bir gerçek."

“Eğitim açısından ilkokul öğrencileri özellikle birinci sınıflar için bana göre olumsuz etkileri olmuştur. Öğrenciler daha yeni okula alışırlarken bir anda bu dönemin böyle bitmesi onları da üzmüştür ve bence bilgileri eksik kalmıştır çünkü bir öğretmen ile yüz yüze diyalog kurmak farklıdır bir video izlemek farklıdır."

Toplumsal Değişiklikler

"Bu süreçten sonra bence artık toplumsal açıdan çoğu alışkanlıklarımız, yaşam biçimimiz değişecek gibi görünüyor. Biz Türk milleti olarak birbirimize sarılan, cana yakın insanlarız. $\mathrm{Bu}$ virüs bittikten sonra bile insanlar bu virüsü unutsalar bile artık bence eskisi kadar sarılma, tokalaşma vs. bunlara benzer alışkanlıklarımızı çekinerek veya biraz daha az yapacağız diye düşünüyorum."

“Covid-19 isimli salgını iyi bir şekilde atlatabilmek için bütün ülkeler farklı yollar deniyor. $\mathrm{Bu}$ dönemde tüm dünyadaki ülkeler kurtuluşa ermek için dayanışma içindeler. Bundan sonra da dayanışma artacaktır bence.” 
"Salgının enteresan bir tarafi var ve bu taraf birçok insana farkındalıklar kazandırdı diye düşünüyorum: İşe gitmek zorunda kalanlar, toplu taşıma kullanmak zorunda kalanlar/kalmayanlar, uzaktan eğitim alan çocukların bilgisayar ve/veya internete sahip olması/olmaması gibi sosyal ve ekonomik farklılıklar var. Salgının ortadan kalkması için toplu mücadele gerekiyor. $\mathrm{Bu}$ mücadele için en büyük gereksinim tüm gelir gruplarının bundan sonra birbirine yardımcı olmayı öğrenmesi olacak."

"Virüs atlatıldığında bile insanlar üzerinde büyük psikolojik hasarlar bırakacağı düşünülüyor. Ölümlerin ve vakaların sayısını azaltmak için bütün ülkeler farklı yöntemler deniyorlar. Tüm dünyada virüse karşı bir dayanışma olduğu görülüyor. Sonrasında da ülkelerin birlikte çözüm odaklı davranmayı öğreneceklerini düşünüyorum.”

“"Herkesin bu ve bunun gibi durumlara karşı artık daha bilinçli olduğunu ve olacağını düşünüyorum.”

"Evlerine kapanan insanlar, sosyal medya aracılığıyla tüm dünyada yaşanan gerçek kaosu ve korkuyu an be an izlediler. Kimsenin bir diğerinden üstün olmadığını, herkesin küçücük bir virüs karşısında ne adar aciz kaldığını, gördüler. Bütün dünya belki de ilk defa birbirine yardım etmek için canla başla çalıştı. İnsanlar tüm hırs ve egolarından sıyrılarak maddi manevi tüm birikimlerini diğer insanlarla paylaştı."

Katılımcılar Covid-19 pandemi sürecinin sonunda tüm insanların birtakım farkındalıklara sahip olacağını, uzaktan eğitimin alt yapısının ve buna bağlı öğretmen eğitiminin gündeme geleceğinin, öğrenmeyi öğrenmenin ön plana çıkacağının, teknolojiyi etkili ve verimli bir biçimde kullanmanın öneminin anlaşılacağı, toplumsal alışkanlıklarımızın değişeceği, ulusların birbirleriyle iyi ilişkiler içinde ve ortak çalışmalar sergileyerek insanlığa katkı sunacağını ifade etmişlerdir. Bu bakış açısı öğretmen adaylarının yaşam boyu öğrenmeye ve yaşam becerilerine ilişkin farkındalıklarının olduğunu ve iyimser (optimist) bir bakış açısıyla olaylara yaklaştıklarını göstermektedir.

\section{Sonuç, Tartışma ve Öneriler}

Yapılan bu araştırmada, sınıf öğretmeni adaylarının COVID-19 Pandemi sürecine ilişkin görüşlerini belirlemek amaçlanmıştır. Araştırmada sınıf öğretmeni adaylarının bilim tarihinden yola çıkarak, yüzyıllar boyunca insanoğlunun birçok salgın hastalıkla yüzleşmek zorunda kaldığını, bilimsel sürecin hastalıklarda güvenilecek en kıymetli yöntem olduğuna inandıkları sonucuna ulaşılmıştır. Bununla beraber öğretmen adaylarının 21. Yüzyılın hızla ilerleyen bilim ve teknolojisine rağmen halâ bir salgın hastalığa kısa sürede çözüm bulunamamasını yadırgadıkları ortaya çıkmıştır.

Araştırmaya katılan öğretmen adayları çocukların sağlıklarının öncelikli olması nedeniyle okulların kapatılmasını olumlu karşıladıkları ve bu süreçte hızla uzaktan eğitime geçilerek EBA'nın hizmete konmasından öğretmen adaylarının memnun oldukları sonuçlarına ulaşılmıştır. Saavedra'ya göre (2020) de günümüz koşullarında en büyük avantaj, eğitim bakanlıklarının sosyal ağlar, WhatsApp veya SMS yoluyla, ebeveynler ve öğretmenlerle etkili bir şekilde iletişim kurabilmeleri ve radyo veya TV tarafından öğrenme içeriği ile eğitim verebilmeleridir. Benzer biçimde Kırmızıgül de (2020) yaptığı çalışmada COVID-19 pandemisi sürecinde öğretmenlerin teknolojik pedagojik alan bilgi ve becerilerinde önemli gelişmeler yaşandığını ve EBA aracılığıyla 
öğretmenler tarafından öğrenciler ödevlendirilerek canlı ders uygulamasına geçilmesiyle birlikte süreç desteklendiğini belirtmiştir.

$\mathrm{Bu}$ araştırmanın sonunda, sınıf öğretmeni adaylarının okula gidememenin çocukları sosyal ve psikolojik olarak sıkıntıya sokacağından ve yüz yüze eğitim sırasında kazandıkları bazı değer ve alışkanlıkları evde uzaktan eğitimle aynı şekilde kazanamayacaklarından endişe ettikleri ortaya çıkmıştır. Öğretmen adaylarının bu endişesine bağlamında Fox (2004) tarafindan yapılan araştırmada da benzer biçimde SARS epidemisinde öğrencilerin, sınıf dışı bir ortamda çevrimiçi öğrenme etkinliklerini tamamlama ve hayata geçirmekte sıkıntı yaşadıkları ortaya çıkmıştır.

Araştırmada sınıf öğretmeni adayları, öğretmenlerin COVID-19 pandemisi sürecinde öğrencileriyle TV yoluyla verilen uzaktan eğitime destek biçiminde canlı dersler yaparak, telefonda mesaj ya da WhatsApp aracılığıyla yazışarak, kimi zaman görüntülü konuşmalar gerçekleştirerek öğrencilerini takip etmeleri ve gereken akademik ve psikolojik desteği vermeleri gerektiği görüşündedirler. UNESCO da hemen hemen tüm ülkelerde öğretmenleri ve okul yöneticilerini öğrenciler ve velilerle iletişimi desteklemek için eğitsel uygulamaları kullanmanın yanı sıra canlı ders vermeleri konusunda da teşvik etmektedir (Chang and Satoko Yano, 2020). Araştırmada ulaşılan çocuklara psikolojik destek verilmesi gerektiğine yönelik sonuç, Çaykuş ve Mutlu Çaykuş (2020) tarafından yapılan çalışmada da vurgulanmış ve COVID-19 sürecinde öncelikle ve özellikle psikolojik destek sunulması ve psikolojik dayanıklılıkları arttırılması gereken grubun çocuklar olduğu belirtilmiştir.

Araştırmada öğretmen adaylarının pandemi sürecinde velilerin ev içinde aile ilişkilerini sıcak tutmalarının, birlikte ders çalışmalarının ve kitap okumalarının, çocuklarının yeni hobiler edinmelerine, yemek yapmalarına, online birçok etkinliğe ücretsiz erişim sağlayarak aile katılımlı kültürel etkinliklere rehberlik etmelerinin yararlı olacağına inandıkları sonucuna ulaşılmıştır. Benzer biçimde Willis (2020) de araştırmasında ilkokul öğrencileriyle meşgul bir ebeveynin yemek pişirme, zamanı bildirme veya temel bir bütçe yapma gibi pratik etkinlikleri büyük öğrenme firsatlarına dönüştürebileceğini belirtmiştir. Kluth (2020) da, aileler tarafından çocuklar için hazırlanacak bir günlük plan çizelgesinde hem dersler için hem de oyun zamanı ve egzersiz için yer açarak bir disiplin ve denge duygusu oluşturulabileceğini belirtmiştir.

Sınıf öğretmeni adayları bu çalışmada velilerin çocuklarının sağlıklarına dikkat etmeleri gerektiğini, hijyen konusunda uyarmalarının önemli ve kaçınılmaz olduğunu ve diğer öz-bakım becerilerinde çocuklarına yardım etmelerinin yararlı olacağını düşündükleri ortaya çıkmıştır. Benzer biçimde Willis (2020) de yayınında, davranış, öz düzenleme ve hijyeni içeren sosyal becerilerin aileler tarafindan verilmesi gerektiği belirtmiştir. Bu araştırmada katılımcılar tarafindan vurgulanan hijyenin pandemi döneminde önemi de bir kez daha farklı biçimlerde ortaya çıkmıştır ve bu konularda hassas davranılması önerilmektedir. An Pan ve arkadaşları (2020) tarafindan yapılan araştırmada, çok yönlü halk sağlığı önlemlerinin (yoğun intrasite ve şehirlerarası trafikte kısıtlama, sosyal uzaklaştırma önlemleri, ev hapsi ve merkezi karantinanın) önemli olduğu ortaya çıkmıştır. Bunlarla birlikte halka açık yerlerde zorunlu maske takılması ve tüm şehir için evde kalma politikası uygulanması ile Wuhan'da COVID-19'da doğrulanmış vaka oranları azaltılmış ve salgın kontrol altına alınmıştır. Temiz eldiven kullanılmalı ve bileği iyi örtmelidirler, kullanımı tamamlandıktan hemen sonra çıkarılmalıdır. Ayrıca cerrahi tek kullanımlık maskeler kullanılabilir; bunlar bir dereceye kadar koruyucu olup, her şeyden önce damlacıklarla yakın teması engellediği için yararlıdır (Cirrincione et.al., 2020).

$\mathrm{Bu}$ araştırmada elde edilen sonuçlardan diğeri ise sınıf öğretmeni adaylarının Covid-19 pandemi sürecinin sonunda tüm insanların bir takım farkındalıklara sahip olacağına, uzaktan eğitimin alt yapısının ve buna bağlı öğretmen eğitiminin gündeme geleceğine, öğrenmeyi öğrenmenin ön plana çıkacağına, teknolojiyi etkili ve verimli bir biçimde kullanmanın öneminin anlaşılacağına olan inançlarıdır. Katılımcıların uzaktan eğitimle ilintili olarak öğretmen eğitiminde değişikliklerin gündeme geleceğine olan inançları, Oleksii ve arkadaşlarının (2018) yaptığı 
araştırmada ulaştığı gelecekteki ilkokul öğretmeninin bilgi ve iletişim yaklaşımı temelinde mesleki eğitimi öğretmenin uzaktan eğitime hazır olmasını gerektirir ve bu da önemli, uzun, tutarlı ve dinamik bir süreçtir sonucuyla örtüşmektedir. Öğrenmeyi öğrenmenin etkili olacağına yönelik bakış açısına paralel olarak Gonzales ve arkadaşları tarafından (2020) yapılan araştırmada COVID19 dolayısıyla okulların kapanmasının öğrencilerin öğrenme stratejilerini daha etkin kullanmaya başladıkları ve bunu bir alışkanlık haline getirerek verimliliklerini arttırdıkları sonucuna ulaşı1mıştır.

$\mathrm{Bu}$ araştırmada katılımcı öğretmen adaylarının, pandemi süreciyle birlikte toplumsal alışkanlıkların değiş̧eceğine, ulusların birbirleriyle iyi ilişkiler içine gireceğine ve işbirliğinin artacağına dair olumlu bir bakış açısına sahip oldukları da ortaya çıkmıştır. Benzer biçimde Favale ve arkadaşlarının (2020) yaptıkları çalışmada da COVID-19 salgınının online alışverişlerin artan kullanımı, çevrimiçi derslere geçiş ve uzaktan çalışma çözümlerinin benimsenmesi gibi insanların yaşamları ve alışkanlıkları üzerinde büyük etkisi olduğu ifade edilmiştir. $\mathrm{Bu}$ araştırmada katılımcıların öğrenmeyi öğrenmenin ön plana çıkacağına, teknolojiyi etkili ve verimli bir biçimde kullanmanın öneminin anlaşılacağına ilişkin inançları, Aldemir ve Avşar (2020)tarafından yapılan araştırma sonuçlarıyla benzerlik göstermektedir. Söz konusu çalışmada da, pandemi döneminde bireylerin çalışmaya evden devam etmek, toplantılara katılmak, uzaktan eğitim derslerine girmek (Skype, Zoom vb. aracılığıyla), durum hakkında araştırma yapmak, gündemi takip etmek veya sadece zaman geçirmek için sosyal medya başta olmak üzere dijital araçlara daha çok başvurmaya başladıkları ifade edilmiştir.

Yapılan bu araştırmada ulaşılan sonuçlar ışığında şu öneriler getirilebilir:

- Öğretmen adaylarının salgın hastalıklar karşısında nasıl davranılması gerektiğine ilişkin bilişsel ve duyuşsal anlamda farkındalığa sahip oldukları ortaya çıkmıştır. Bu farkındalıkların büyük örneklemlerde ne durumda olduğunu görebilmek için nicel çalışmalar yoluyla ilgili ölçekler geliştirilerek geniş kitlelere ulaşılması gerekmektedir.

- Bu araştırmada öğretmen adaylarının pandemi sürecinde ilkokul öğrencilerinin eğitim durumuna ilişkin görüşleri alınmıştır. Daha sonraki çalışmalarda öğretmen adaylarının kendi akademik yaşamlarına pandeminin etkisi araştırılabilir.

- COVID-19 tüm dünyada yaşanan bir pandemi olduğu için bu sürecin çocuklar ve öğretmen adayları üzerindeki etkileri eğitsel, sosyolojik ve psikolojik bağlamda araştırılabilir.

\section{Kaynakça}

Aldemir, C. \& Avşar, M. N. (2020). Pandemi döneminde dijital vatandaşlık uygulamaları. Avrasya Sosyal ve Ekonomi Araştırmaları Dergisi, 5(2),148-169.

Altunışık, R., Coşkun, R., Yıldıım, E. \& Bayraktaroğlu, S. (2001). Sosyal bilimlerde araştırma yöntemleri. Sakarya Kitabevi.

An Pan, Li L., Chaolong W, Huan G., Xingjie H., Qi W., Jiao H., Na H., Hongjie Y., Xihong L., Sheng W. \& Tangchun W. (2020). Association of Public Health Interventions With the Epidemiology of the COVID-19 Outbreak in Wuhan, China. JAMA, 323(19), 1915-1923.

Arthur, J., Waring, M., Coe, R. ve Hedges, L.V. (2017). Eğitimde araştırma yöntemleri ve metodolojileri. (Çev. Ed. Erözkan A. ve Büyüköksüz, E.) Anı Yayıncılık.

Chang, G. C. \& Yano, S. (2020 Nisan). How are countries addressing the Covid-19 challenges in education? A snapshot of policy measures. https://gemreportunesco.wordpress.com/2020/03/24/how-are-countries-addressing-thecovid-19-challenges-in-education-a-snapshot-of-policy-measures/ 
Christensen, L. B., Johnson, R. K. ve Turner, L. A. (2015). Araşttrma yöntemleri, desen ve analiz. (Çev. Ed. Aypay, A.) Anı Yayıncılık.

Cirrincione, L., Plescia F., Ledda C., Rapisarda V., Martorana D., Moldovan R. E., Theodoridou K. \& Cannizzaro, E. (2020). COVID-19 Pandemic: Prevention and Protection Measures to Be Adopted at the Workplace, Sustainability, 12(3603), 1-18.

Çaykuş, E. T. \& Mutlu Çaykuş, T. (2020). COVID-19 pandemi sürecinde çocukların psikolojik dayanıklı1ı̆̆ını güçlendirme yolları: ailelere, öğretmenlere ve ruh sağlığı uzmanlarına öneriler. Avrasya Sosyal ve Ekonomi Araştırmaları Dergisi (ASEAD), 5(2), 91-113.

Favale, T., Soro, F., Trevisan, M., Drago, I. \& Mellia, M. (2020 Mayı). Campus Traffic and eLearning during COVID-19 Pandemic. https://proxy.afyon.deepknowledge.net/MuseSessionID=0210j3mny/MuseProtocol=https/ MuseHost=search.proquest.com/MusePath/publiccontent/docview/2396050276/FC7A4CA 4D6C0416EPQ/1?accountid=15333

Fox, R. (2004). SARS epidemic: Teachers' experiences using ICTs. In Beyond the comfort zone: Proceedings of the 21st ASCILITE Conference, 5-8 December 2004, p. 319-327.

Gonzalez, T., M A de la Rubia., Hincz, K P., Comas-Lopez, M., Subirats, L., Sacha G M. (2020 Mayıs). Influence of COVID-19 confinement in students' performance in higher Education. https://proxy.afyon.deepknowledge.net/MuseSessionID=0210j3mny/MuseProtocol=https/ MuseHost=search.proquest.com/MusePath/publiccontent/docview/2393251889/9F1301B6 80C34DB8PQ/1? accountid=15333

Güner, R., Hasanoğlu, İ. \& Aktaş, F. (2020). COVID-19: Prevention and control measures in community. Turkish Journal of Medical Sciences, 50: 571-577.

IITE-UNESCO (2020 Nisan). Facebook in cooperation with UNESCO IITE, ISTE and other partners launched a digital literacy program, Get Digital. https://iite.unesco.org/news/facebook-in-cooperation-with-unesco-iite-iste-and-otherpartners-launched-a-digital-literacy-program-get-digital/

Kırmızıgül, H. G. (2020). COVID-19 salgını ve beraberinde getirdiği eğitim süreci. Avrasya Sosyal ve Ekonomi Araştırmaları Dergisi, 5(2), 283-289.

Kluth, A. (2020, Mayıs). Closing School May Cause Some Kids a Lifetime of Harm. http://0210g3mmx.y.http.eds.a.ebscohost.com.proxy.afyon.deepknowledge.net/eds/detail/d etail?vid=12\&sid=f01d2801-89e3-436f-b5f3-

Oleksii P. M., Kolos, K. R. \& Kolomiiets, N. A. (2018). Distance Learnıng Of Future Prımary School Teachers As A Prerequisite Of Their Professional Development Throughout Life, Information Technologies and Learning Tools, 66, 4.

Saavedra, J. (2020 Nisan). Educational challenges and opportunities of the Coronavirus (COVID19)pandemic.https://blogs.worldbank.org/education/educational-challenges-andopportunities-covid-19-pandemic

UNICEF (2020, Nisan). What is a 'novel' coronavirus? https://www.unicef.org/stories/novelcoronavirus-outbreak-what-parents-should-know\#how- can-avoid-risk-infection

UNESCO (2020, Nisan). Education: From disruption to recovery. https://en.unesco.org/covid19/educationresponse

WHO (2020, Nisan). What is a coronavirus? https://www.who.int/news-room/q-a-detail/q-acoronaviruses 
Willis, A. (2020 May1s). Students won't get through all school content while learning at home: here are 3 things to prioritise. https://theconversation.com/students-wont-get-through-allschool-content-while-learning-at-home-here-are-3-things-to-prioritise-134539

Yıldırım, A. \& Şimşek, H. (2013). Sosyal bilimlerde nitel araştırma yöntemleri. (Beşinci Baskı). Seçkin Yayıncılık.

Yıldız, A., Çetinkaya, M., Leventoğlu, S. \& Şenköylü, A. (2020). Recommendations for Surgical Interventions during COVID-19 Pandemic, GMJ, 31: 283-286. 